The relation between intensity of ultraviolet radiation and cutaneous malignancy is complex. Current models suggest, however, that ozone depletion may cause a more rapid increase in melanoma than in non-melanoma skin cancer. ${ }^{10}$ This is because short episodes of intense and burning ultraviolet exposure are linked to melanoma, whereas nonmelanoma skin cancer is associated with the lifetime build up of exposure to ultraviolet.

To quantify changes in incidence and risk of skin cancer caused by the depletion of ozone is clearly important, but changes in holiday and clothing habits may make it impossible to attribute a percentage of the increased cancers to this depletion.

What action is required? Firstly, more nations should set up monitoring equipment at various locations to record ultraviolet changes through the entire ultraviolet $\mathrm{A}$, ultraviolet $B$, and ultraviolet $C$ portions of the spectrum. Secondly, those who have recently spent a long time in Antarctica should be observed for cutaneous malignancies. The outdoor protection needed in the Antarctic may well, however, have effectively protected people against ultraviolet." Resident fauna such as the Emperor penguins may show ocular damage induced by ultraviolet and might merit a field study. Plankton in the surface waters around Antarctica may for the first time in their evolutionary history experience ultraviolet $\mathrm{B}$ or ultraviolet C. Lastly, the Montreal convention, signed last
September, should be strengthened..$^{12}$ The convention aims at reducing the production of chlorofluorocarbons by half by the end of the 1990s. This is too little and too late. A drastic reduction of chlorofluorocarbon production is needed as soon as possible to prevent an environmental problem becoming an environmental catastrophe.

Professor of Dermatology,

RONA M MACKIE

University of Glasgow,

Glasgow G11 6NU

Head,

MICHAEL J RYCROFT

Upper Atmospheric Sciences Division,

British Antarctic Survey,

Cambridge CB3 0ET

Farman JC, Gardiner BG, Shanklin JD. Large losses of total ozone in Antarctica reveal seasona $\mathrm{Cl}_{\mathrm{x}} / \mathrm{NO}_{\mathrm{x}}$ interaction. Nature 1985;315:207-10.

Thrush B. Causes of ozone depletion. Nature 1988;332:784-5.

Lindley D. CFCs cause part of global ozone decline. Nature 1988;332:293.

Kiehl JT, Boville BA, Briegleb BP. Response of a general circulation model to a prescribed Antarctic ozone hole. Nature 1988:332:501-4.

Rycroft MJ. Where has all the ozone gone? Physics Bulletin 1987;38:410-1.

6 Anderson A. Depletion of ozone layer drives competitors to cooperate. Nature 1988;331:201.

7 Scotto J, Cotton G, Urbach F, Burger D, Fears T. Biologically effective ultraviolet radiation

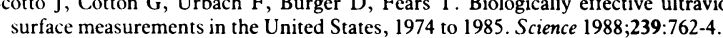

surace measurements in the United Stat: 1974:

Geardsley T. Deaths foreld. Nature 1986;324:102. 1988;296:13-7.

0 Mackie RM, Aitchison TC Severe sunburn and subsequent risk of primary cutaneous melanoma. Br f Cancer 1982;46:955-60.

11 Anderson A. Antarctica not the place for sun worshippers. Nature 1987;330:2.

12 Johnston K. First steps in ozone protection agreed. Nature 1987;329:189.

\title{
Prophylactic sclerotherapy for varices
}

\author{
Useful only in limited circumstances
}

Sclerotherapy stops variceal bleeding, ${ }^{1}$ reduces rebleeding, ${ }^{2}$ and improves survival. ${ }^{+}$Yet about a third of patients still die from an episode of variceal bleeding. ${ }^{256}$ Is there a case for prophylactic sclerotherapy? The answer would undoubtedly be yes if three conditions were fulfilled: the procedure was innocuous; all patients with varices were eventually to bleed; and the risk of death during a bleed was substantial and the same in all groups. Unfortunately none of these conditions is fully met.

Sclerotherapy is not innocuous. Non-fatal complications include stricture formation and dysphagia in 10-30\% of patients. ${ }^{5 \times}$ Moreover, 1-7\% of patients die of bleeding from ulceration after sclerotherapy, oesophageal perforation, and mediastinitis. $^{79.11}$ Paralysis of the spinal cord has also been recorded. ${ }^{12}$

Not all patients with varices do bleed. Only $10-20 \%$ of the controls in large trials of prophylactic shunt operations bled each year during the first two years, and only a fifth died..$^{13-15}$ In such a population 1800 patients would be needed to prove that prophylactic sclerotherapy reduced mortality by $25 \%$. $^{16}$

Until such a trial is available is it possible to select subgroups who are more likely to bleed or in whom a bleed is more or less likely to be fatal? Admission mortality is strongly dependent on functional hepatic reserve as measured, for instance, by a modified Child's grade. ${ }^{17}$ Only about $6 \%$ of those with the most reserve will die after the first bleed. Similarly, only one out of 159 children and young adults with extrahepatic block died after the first bleed. ${ }^{1819}$ Thus the potential benefit of prophylactic sclerotherapy is low among those with the most hepatic reserve.

Those with less reserve, however, have a high risk of death during their first bleed. There might be potential for improving survival among them by prophylactic sclerotherapy, especially if there are other indications that they are likely to bleed soon. Such increased risk is shown by large variceal size ${ }^{2021}$ prolonged prothrombin time, ${ }^{22}$ the presence of red spots or weals over the varices, ${ }^{21-23}$ and continuing abuse of alcohol in those with alcoholic cirrhoses. ${ }^{24}$

Paquet included endoscopic signs of impending variceal bleeding to select a group at high risk for a controlled trial of prophylactic sclerotherapy..$^{22}$ Mortality was significantly reduced from 14 out of $33(42 \%)$ in controls to 2 out of $32(6 \%)$ in treated patients at two years. Bleeding episodes were also reduced from 22 out of $33(66 \%)$ to 2 out of $32(6 \%)$. In a less selected series Witzel et al noted a reduction in mortality from 29 out of $53(55 \%)$ in controls to 12 out of $56(21 \%)$ over 25 months in the group given sclerotherapy. ${ }^{25}$ Bleeding occurred in 30 out of $53(57 \%)$ in the controls and five out of $56(9 \%)$ in the treated group. These trials have been criticised not least because the control groups had unusually high mortality and rates of bleeding, at least compared with controls from historical trials of prophylactic portacaval shunts and other studies. ${ }^{26}$ The contrary view is that the very purpose of having a control group in a study is to avoid reliance on comparison with patients from other studies, continents, and decades.

Three large randomised trials have been reported recently, and are not optimistic about the benefits of prophylactic sclerotherapy. ${ }^{27-29}$ Sauerbruch et al performed prophylactic sclerotherapy in 41 out of 103 patients with cirrhosis and large varices. ${ }^{27}$ During an average follow up of 17 months mortality was decreased in the group given sclerotherapy (20\%) compared with the control group (35\%). Yet a similar proportion of each group had variceal bleeding (29\% against $35 \%$ ). Bleeding occurred earlier in the group given sclerotherapy (mean 4.1 months) than in the control group (mean 6.7 months) and may have been precipitated by sclerotherapy. 
Ulceration may account for half or more of rebleeding episodes in those given sclerotherapy. ${ }^{30}$ Such episodes were often minor and rarely fatal. When the prognosis of a first variceal bleed occurring during prophylactic sclerotherapy is different from that of a first variceal bleed occurring "spontaneously" it may limit the usefulness of this item as an end point in a clinical trial.

The randomised study of 282 men with alcoholic cirrhosis reported by Gregory et al was even less encouraging. ${ }^{2 x}$ By 22 months mortality in the group given sclerotherapy so exceeded that in the control group (29\% against $17 \%$, $\mathrm{p}=0.009$ ) that the trial was stopped. More treated patients also had bleeding episodes ( $22 \%$ against $16 \%, p=0.02)$. The most recent randomised study by Santangelo. et al in 95 patients with large varices again showed no benefit in the group given prophylactic sclerotherapy. ${ }^{29}$ Mortality was a quarter in both treated and control groups at 13 months. Moreover, there was an excess of episodes of early fatal bleeding in the group given sclerotherapy.

All large centres should know their rate of complication for sclerotherapy and the prognosis of their patients with varices that have not bled. Prophylaxis sclerotherapy should be considered only if this prognosis is similar to that of the controls in Witzel's study or if the patients have factors that put them at high risk, such as the variceal appearance of those in Paquet's trial, and only then if they are being managed in a centre with a low complication rate for variceal sclerotherapy. Otherwise prophylactic sclerotherapy offers little benefit, and most patients will be better served by regular review.

\section{W BULLIMORE}

Lecturer

P FOSTER

Department of Medicine,

St James's Hospital,

Leeds LS9 7TF

1 Barsoum MS, Bolous FI, Bil-Rexby AA, Rizk-Allah MA, Ibrahim AS. Tamponade and injection sclerotherapy in the management of bleeding (eesophageal varices. Br 7 Surg 1982:69:76-8.

2 Terblanche J, Bornman PC, Kahn D, et al. Failure of repeated injection sclerotherapy to improve long-term survival after wesophageal variceal bleeding. A tive vear prospective controlled clinical 983:ii:1328-32

3 Kitano S, Kovanagi N, Iso Y, Higashi H, Sugimachi K. Prevention of recurrence of esophageal varices after endoscopic injection sclerotherapy with ethanolamine oleate. Hepatologv 1987;7 $810-5$

+ Westaby D, Macloougall BRD, Williams R. Improved survival following injection sclerotherapy for esophageal varices: final analysis of a controlled trial. Hepatologr 1985;5:827-30.

5 Sorensen T. Burcharth F. Pedersen MI., Findahl F. Oesophageal stricture and dvsphagia after endescopic sclerotherapy for blecding varices. (jut 1984:25:473-7.

6 Bullimore DW. Bleeding oesophageal varices: referral bias and survival. 7 R Coll Phwicians Lomd 1985:19:189-91.

Williams R, Westaby D. Lindoscopic sclerotherapy for esophageal varices. Dig Dis Sii 1986:31: $108-21 \mathrm{~s}$

8 Smith PM, Jones DB, Rose JDR. Simplified fibre endoscopic sclerotherapy for oesophageal varies. IR Coll Physiciens Liond 1982:16:236-8.

9 Van Heotegem P'h, Rutgerts P. Feverv J. Brockaert L, De Groote J, Vantrappen G. Sclerotherapy of (eseophageal varices after variceal haemorrhage. Endoscops. 1984;16:95-7.

10 Bacon BR, Camara DS. Duffy MC. Severe ulceration and delaved perforation of the esophagus after endescoipic variceal scleresheraps. (iastrointest Endosic 1987:33:311-5.

11 Barsoum MS, Mexro HA, Bolous FI, Ram $\%$ AF, Ri\%k-Allah MA, Mahmoud FI. The complications of injection sclerotherapy of blecding owsophageal varices. Br 7 Surg 1982;69. 79-81.

12 Seidman 1:, Wether AM. Morin CL, at al. Spinal cord paralysis following sclerotherapy for esophageal varices. Hepatologv 1984:4:950-4.

13 Resnick RH, Chalmers TC, Ishihara AM, ct al. A controlled study of the prophylactic portacaval shunt. A tinal report. Ann Intem Med 1969;70:675-88.

I Jackson FC. Perrin EB, Sinith AG, at al. A clinical investigation of the portacaval shunt. II. Survival analysis of the prophylactic operation. Am. . Surg 1968:115:22-42.

15 Conn HQ, Lindenmuth WW, May CJ, Ramsby GR. Prophylactic portacaval anastomosis. A tale of two studies. Medicinc (Baltimore) 1972:51:27-40.

16 Burroughs AK. D'Hevgere F, McIntvre N. Pitfalls in studies of prophylactic therapy for variceal bleceding in cirrhotics. Hepatologn 1986:6:1+07-13.

17 Pugh RNH, Murray-Lyon IM. Dawson JL, Pietroni MC, Williams R. Transection of the cesophages for blecding (e'sophageal varices. Br 7. Surg 1973;60:6+6-9.

8 Wetib LJ, Sherlock $S$. The actiolegy, presentation and natural history of extra-hepatic portal Wetb $L$ J, Sherlock S. The actiology, presentation
renous obstruction. Q.7. Med 1979;48:627-39.

19 Aovama K, Mvers NA. Extra-hepatic portal hypertension: the significance of variceal hacmorrhage. Iust Pacdiatr. 7 1982:18:17-22.

20 Westaby S, Wilkinson SP, Warren R, Williams R. Spleen size and portal hypertension in cirrhosis. Digestion 1978:17:63-8

21 Dagradi AE, Stempien SI, Owens LK. Bleeding esophogastric varices. Arch Surg 1966:92:944-7.

22 Payuet KJ. Prophylatic endoscopic selerosing treatment of the esophageal wall in varices-a prospective controlled randomized trial. Eindoscopy 1982;14:-5.

Beppu K. Inokuchi K, Kovanogi N, at al. Prediction of variceal hemorrhage by esophageal endoscopv. (iastrointest Endosc 1981:27:213-8.

24 Dagradi $\mathrm{Al}$. The natural history of esophageal varices in patients with alcoholic liver cirrhosis. Im 7 (jastrocmerol 1972:57:520-40.

25 Witzel L, Wolbergs L, Merki H. Prophylactic endoscopic sclerotherapy of oesophageal varices. A prospective controlled studv. Lancet 1985 :i: $773-5$.

26 Burroughs AK. Hamilton G. Prophwlactic endoscopic variceal sclerotherapv of exesophageal varices. Lancel 1985; i1105-6.

27 Sauerbruch T, Wotza R, Kopcke W, at al. Endoscopic sclerotherapy ST T for prophylaxis of first variceal bleeding in liter cirrhosis. Early results of a prospective randomized trial. (Gustrocnterolege' 1986;90:1765

28 (iregory P. Hartigan P, Amodeo D, at al. Prophylactic sclerotherapy for esophageal varices in alcoholic liver discase: results of a VA co-operative randomized trial. (jastroenterologe 1987;92: $1+14$

29 Santangelo WC, Dueno MI, Lstes BL, Krejs GJ. Prophwlactic sclerotherapv of large esophageal varices. N Engl F Afed 1988:318:814-8

30 Westaby D, Melia W, Hegarty W', Gimson AES, Stellon AJ, Williams R. Use of propranolol to reduce the rebleeding rate during injection selerotherapy prior 10 variceal obliteration. Hepulologr 1986;6:673-5.

\section{The new public health}

\section{Implementation of the Acheson report is an opportunity for a radically new public health}

Even in their worst moments during the implementation of general management in the NHS community physicians clung to the certainty that if they were abolished they would have to be reinvented. Witness, for instance, the increasing need for vigilance against communicable diseases illustrated by the recent rise in the incidence of human immunodeficiency virus, legionella, measles, salmonella, and listeria infections. ${ }^{1}$ Moreover, no health service can sensibly operate without disease prevention and health promotion and without analysing needs and evaluating outcome. So it is welcome, if unsurprising, that the recommendations of the Acheson inquiry, Public Health in England, ${ }^{2}$ are to be implemented ( $\mathrm{p}$ 378). Many community physicians, particularly those in communicable disease control, health promotion, and planning, will find the implementation of Acheson an opportunity to show what could have been achieved all along given the right backing, but the new directors of public health now have a chance to develop a new and radically different practice of public health.
Independent advocacy, though a popular concept among community physicians, was dismissed by the Acheson inquiry. In fact, public health physicians still can and should shout their case loudly and publicly, ${ }^{3}$ especially with the help of their new annual reports. But they would rarely achieve the policy changes they advocate if they were limited to heckling from the sidelines without being responsible or accountable for the result. Those who want that kind of freedom have misunderstood the nature of power in the health service and would lose public health the great potential which it now has.

On the other hand, if the implementation of the Acheson report were to represent a takeover bid by overweening community physicians resorting to the autocratic habits of many old medical officers of health, it would be doomed to well deserved failure. A vast array of professionals and others outside as well as within the health services are concerned with public health, and real leadership should mean ensuring that all these people work towards understood and shared goals. Power and skill need to be devolved to others so that 